Uşak Üniversitesi Sosyal Bilimler Dergisi

$2015,8 / 3$

\title{
Eğitim Fakültesi Öğrencilerinin Okuma Alışkanlıkları Profili
}

\author{
Derya YILDIZ \\ Dilek CERAN** \\ Hasan SEVMEZ ${ }^{* *+}$
}

\section{Öz}

Profesyonel öğretmen tanımlamasındaki özelliklere sahip olabilmek, okuma alışkanlığı ve kültürü edinmiş olmakla doğrudan ilişkilidir. Bu bağlamda öğrencileri tarafından model alınacak olan öğretmen adaylarının okuma alışkanlıklarının iyi düzeyde olması önem taşımaktadır. Bu araştırmanın amacı Necmettin Erbakan Üniversitesi Ahmet Keleşoğlu Eğitim Fakültesi öğrencilerinin okuma alışkanlığı profillerini belirlemektir. Araştırmanın sonuçlarına göre; öğretmen adaylarının; çoğunlukla 1-5 kitap okudukları, okumalarına engel olan unsurlar arasında ilk sırada "Okuma alışkanlığının olmaması"nı seçtikleri; okuma alışkanlıklarının sınıf düzeyine göre belirgin biçimde farklılaşmadığı; okumalarında etkili olan unsurlarda ilk sırada "arkadaş tavsiyesi"; en çok tercih ettikleri türler arasında ilk sırada roman ve hikâyenin yer aldığı; ağırlıklı olarak bölümlerde okumanın, internetin ve TV'nin 1 saatten az, arkadaşlarla vakit geçirmenin 2- 3 saat olduğu; en çok tercih edilen materyaller arasında ilk dörtte sosyal paylaşım sitelerindeki yazılar, edebî kitaplar, internet ortamındaki gazeteler ve dinî dergilerin yer aldığı, en çok okunan Türk yazarların İskender Pala, Elif Şafak, Sinan Yağmur, Canan Tan ve Reşat Nuri Güntekin; en çok okunan yabancı yazarların ise Khaled Hosseini, Adam Fewer, Cengiz Aytmatov, Dostoyevski ve Victor Hugo olduğu tespit edilmiştir.

Anahtar Kelimeler: Eğitim Fakültesi Öğrencileri, Okuma, Okuma Alışkanlı̆̆ 1 .

* Dr., Necmettin Erbakan Üniversitesi, Türkçe Eğitimi Bölümü, dcyildiz@konya.edu.tr

* Yrd. Doç. Dr., Necmettin Erbakan Üniversitesi, Türkçe Eğitimi Bölümü, dlkcrn@yahoo.com

**** Uzman, Selçuk Üniversitesi, hsevmez@selcuk.edu.tr 


\title{
Reading Habits Profile of Faculty of Education Students
}

\begin{abstract}
Having the characteristics given in the definition of professional teacher is directly associated with reading habit and culture. In this regard, having reading habit at a good level is important for teacher candidates who are taken as models. The purpose of this research is to determine reading habit profiles of undergraduates of Necmettin Erbakan University Ahmet Keleşoğlu Faculty of Education. According to the results of the research; it was detected that most of the teacher candidates read 1-5 books, they selected "Not having reading habit" option principally among the factors preventing their reading; their reading habit did not change as to class levels distinctly; "advice from a friend" took the top place among the factors which were effective on their reading; novel and story took the top place among the genres preferred by them; reading in their department predominantly, the internet and TV lasted less than 1 hour, hanging out with friends took 2-3 hours; the writings on the social networking sites, literary books, newspaper on internet and religious magazines were in the first four among the materials mostly preferred, most widely read Turkish writers included İskender Pala, Elif Şafak, Sinan Yağmur, Canan Tan and Reşat Nuri Güntekin; most widely read foreign writers included Khaled Hosseini, Adam Fewer, Cengiz Aytmatov, Dostoyevski and Victor Hugo.
\end{abstract}

Key Words: Faculty of Education Students, Reading, Reading Habit.

\section{Giriş}

Örgün eğitim sürecinde bireylere kazandırılması hedeflenen temel amaçların başında okuma becerisi ve okuma alışkanlığı gelmektedir. Gelişen dünyada bilgiye farklı kanallardan ulaşmak mümkün olmakla birlikte, bu kanalların pek çoğu iyi bir okuyucu olmaktan geçmektedir. Okuma, "ses organları ve yoluyla algılanan işaret ve sembollerin beyin tarafindan yorumlanarak değerlendirilmesi ve anlamlandırılması süreci" (MEB, 2006: 6) olarak tanımlanmaktadır. Okumayı; bilişsel davranışlarla psikomotor becerilerin ortak çalışmasıyla yazılı sembollerden anlam çıkarma etkinliği (Demirel, 1999: 65); sözcüklerin, duyu organları yoluyla algılanıp anlamlandırılmasına, kavranmasına ve yorumlamasına dayanan zihinsel bir etkinlik (Sever, 2011: 12); ön bilgilerin kullanıldığı, yazar ve okuyucu arasındaki etkili iletişime dayalı, uygun bir yöntem ve amaç doğrultusunda, düzenli bir ortamda gerçekleştirilen anlam kurma süreci" (Akyol, 2005: 1) 
şeklinde tanımlamak da mümkündür. Kayalan (2000) ise okumayı, bir yazar tarafından görsel uyarıcı biçimde kodlanan anlamın, okuyucunun aklında bir anlam çıkarmasını sağlayan bir etkileşim olarak ifade etmiştir.

Okumayla ilgili tanımların ortak vurgusu okumanın; anlama ya da anlam kurma süreci boyutudur. Yeni bir anlam oluşturma süreci olarak kabul edilen okuma, Sever'e (2011) göre; iletişim, algılama, öğrenme, bilişsel, duyuşsal ve devinişsel boyutlu bir süreçtir. Anlaşılacağı üzere okuma; sadece bir metni anlama çabası değil, metinlerden hareketle olayları ve durumları görebilme, değerlendirebilme ve yönlendirebilme becerisidir. Dolayısıyla toplumsal ilerleme ve gelişmişlik, "bireyin entelektüel gelişiminin temeli olan okuma" (Gönen, 2007: 61) ve toplumdaki okuyan birey sayısı ile doğrudan ilişkilidir. Bu bakımdan okuma sadece Türkçe dersinin değil bütün derslerin ve eğitim-öğretim sürecinin başat ögelerinden biri olarak görülmelidir. “Okuma okul programlarının omurgası niteliğini taşır. Hemen her derste okumanın önemli bir yeri vardır. İyi okuyamayan ya da okuduğunu tam olarak anlayamayan bir öğrencinin derslerinde başarı göstereceği söylenemez" (Özdemir, 1967: 117).

$\mathrm{Bu}$ anlamda okuma becerisinin hayatın bütün aşamalarına yayılan bir alışkanlık olması gerektiği düşüncesi ortaya çıkmaktadır. Ancak okumanın bir beceri olmanın ötesinde bir alışkanlık ve ihtiyaca dönüşmesi oldukça zor bir süreçtir. Alışkanlık, "bir şeye alışmış olma, yakınlık, arkadaşlık kurma, iç ve dış etkilerle davranışların tekrarlanması, hep aynı biçimde gerçekleşmesi sonucu beliren şartlanmış davranış; alışma, bir işi tekrarlayarak kolaylıkla yapabilir hale gelmek, o işi sürekli ister olmak" (TDK, 1998: 83) demektir. Alışkanlık, öğrenilen ve her durumda otomatik olarak gerçekleştirilecek şekilde pekiştirilen karakteristik davranış biçimi (Blaha ve Bennett, 1993: 86) olarak da tanımlanabilir. Alışkanlıklar insan hayatına yavaş yavaş girer ve ancak belli bir süre sonra kökleşir. Alışkanlıklar bırakılmadığı takdirde zamanla bir ihtiyaç haline gelir.

Okuma alışkanlığı ise en kısa ve öz tanımıyla okuma eyleminin sürekli tekrar edilmesi ve bireyin günlük hayatının vazgeçilmez bir parçası haline gelmesidir. Kayalan (2000) okuma alışkanlığını, kendini çevreyi ve dünyayı anlayabilmede okumayı temel araç olarak kabul etme ve kullanma isteği ile bunu sürekli hale getirmek; Yılmaz (1993) ise "bireyin bir gereksinim ve zevk kaynağı olarak algılaması sonucu okuma eylemini yaşam boyu, sürekli, düzenli ve eleştirel bir biçimde gerçekleştirmesi" şeklinde ifade etmektedir. Özbay (2007) okuma alışkanlığını, insanın kendisini ve yaşama çevresini anlayabilmek için okumayı bir araç olarak görmesi ve bu aracı kullanma isteği olarak tanımlar. 
Gelişen ve değişen dünyadaki yaşam boyu öğrenme ilkesinin devamlı ve sağlıklı yürütülebilmesinin temeli bireye okuma alışkanlığı kazandırmakla mümkündür. Bireyin okumayı öğrenmesiyle birlikte, okumayı sevdirecek, kitaplarla arasında bir diyalog ve bağ oluşmasını sağlayacak adımlar atılmalıdır. Bireyleri okumaya yöneltmede ilk adım, bireylerin ihtiyaçlarını ve ilgilerini bilmek ve onları bu doğrultuda yönlendirmektir. Ayrıca bireyi okumanın gerekliliğine ve ona sağlayacağı katkılara inandırmak da okumanın alışkanlığa dönüşmesine yardım edecektir. Birey; okumanın şahsi, mesleki ve sosyal hayatına katkısına inandığı zaman bireysel olarak okumaya ihtiyacı olduğunu görecektir. Bu da doğuştan gelen ilgilerin ve ihtiyaçların karşılanması ile başlar, okumanın getirdiği kazancı kavrama ile devam eder ve sonunda da kitaplarla düzenli bir arkadaşlığa dönüşür (Bamberger, 1990: 44). İlgi ve ihtiyaçların yanı sıra okumanın alışkanlığa dönüşmesi pek çok etkene bağlıdır. Bu etkenler içinde, kültürel değerler, ekonomik durum, eğitim sistemi, aile kurumu ve okumaya daha uygun ve kısa yolla kitap, dergi vs. sağlayan kaynaklar sayılabilir (Özçelebi ve Cebecioğlu, 1990: 43).

Bununla birlikte okuma her ne kadar bireysel bir faaliyet gibi görülse de söz konusu etkenler okumanın bireysellikten öte toplumsal ve kültürel bir yapıya da sahip olduğuna işaret etmektedir. Bireysel olarak değerlendirilen okuma alışkanlıkları bir bütün arz ettiğinde bir toplumun gelişmişlik düzeyi, gelişime ve değişime açıklığı hakkında ciddi ipuçları vermektedir. Yaygın kanaat Türkiye'de okuma alışkanlığının yeterli olmadığı yönündedir. 1998 yılında yapılan bir araştırmada "son bir yılda roman ya da şiir türünden kaç kitap okudunuz?" sorusuna katılımcıların \% 41,09'u " hiç okumadım" cevabını vermiştir (Cekinhad, 2000). Türkiye'nin okuma alışkanlığı üzerine yapılan bir başka araştırmada (Çocuk Vakfı, 2006) ise gençlerin \% 70'inin hiç okumadığ1, öğretmenlerin de \% 63'ünün bazen okuduğu ortaya konulmuştur. Kütüphaneler ve Yayımlar Genel Müdürlügünün Türkiye Okuma Kültürü Haritası Projesinden (2011: 8), elde edilen bilgiler de okuma alışkanlıklarının profili hakkında ipuçları vermektedir. $\mathrm{Bu}$ projenin sonuçlarına göre Türkiye'de; Seçici ve düzenli okuyanların yılda ortalama 14.5 kitap; 7-14 yaş grubu bireylerin yılda ortalama 12 kitap; kadınların yılda ortalama 7.3 kitap; erkeklerin yılda ortalama 7.1 kitap; bekârların yılda ortalama 10.1 kitap; yaşamının büyük kısmını büyükşehirde geçirenlerin yılda ortalama 7.7 kitap; aylık $3001-5000 \mathrm{TL}$ arasında geliri olanların yılda ortalama 10.9 kitap; 4 kişilik bir ailenin yılda ortalama 7.6 kitap; evinde internet bağlantısı bulunanlar yılda ortalama 8.4 kitap; öğrencilerin ise yılda ortalama 11.1 kitap okuduğu tespit edilmiştir. 
Okumanın bir alışkanlık şeklini alması okuyucu tiplerini de ortaya çıkarır. Okuma alışkanlığı düzeyinin sınıflandırılmasında dünyada en yaygın kabul gören ölçüt, Amerikan Kütüphane Derneği'nin (American Library Association-ALA) önerdiği standarttır. Bu standarda göre okuma alışkanlığ 1 düzeyleri bireylerin bir yıl içinde okudukları kitap sayısına göre üç tür altında sinıflandırılmaktadır.

-Yılda okuduğu kitap sayısı 5'i geçmeyen kişiler, az okuyan okur tipi,

-Yılda okuduğu toplam kitap sayısı 6 ile 20 arasında olanlar, orta düzeyde okuyan okur tipi,

-Yılda okuduğu toplam kitap sayısı 20'yi aşan kişiler ise çok okuyan okur tipi olarak nitelendirilmektedir (ALA, 1978'den aktaran Yılmaz, 2004)

Sayısal veriler toplumların okuma alışkanlıkları hakkında ipucu vermekle birlikte, bu sonuçlardan okumanın niteliği üzerine tespitlerde bulunmak zordur. Okunan kitap sayısı kadar okumanın niteliği de önemlidir. Okuma; öğrenmeyi, araştırmayı, yorumlamayı, eleştirel düşünmeyi, tartışmayı beraberinde getirdiği takdirde anlamlı ve etkili bir sürece dönüşür. Okuyucu, Bamberger'in (1990: 18) ifadesiyle "işlevsel okuryazarlık" seviyesine ulaştığında okumanın bireye ve topluma katkısı olur. Zaten okumanın niteliği ile kişinin niteliği arasında bir paralellik söz konusudur.

Nitelikli insan yetiştirme örgün eğitimin her basamağının sorumluluğundadır. Ancak özellikle belli bir olgunluğa erişmiş ve kendi kendine yetebilen yani hayatını ihtiyaç ve ilgileri doğrultusunda şekillendirebilen gençleri bünyesinde barındıran üniversitelerin bu konuda daha işlevsel bir rol üstlenmesi gerekmektedir. Üniversiteler öğrenciyi hazır bilgiyi tüketen değil; araştıran, bilgi üreten, tartışan, sorgulayan bireyler olarak yetiştirmekle yükümlüdür. Dolayısıyla toplumun geleceğine yön verecek bu bireylerin söz konusu becerileri edinmelerinde okumaya daha çok yönlendirilmeleri beklenir. Ancak yapılan araştırmalar, (Gömleksiz, 2004; Odabaş, Odabaş ve Polat, 2008; Saracaloğlu, Yazıc1, 2003; Yılmaz, 2009) üniversite öğrencilerinin de iyi bir okuma alışkanlığına sahip olmadığını ortaya koymaktadır.

Eğitim Fakülteleri ülkeye öğretmen yetiştiren kurumlardır. Söz konusu öğrencilerin öğretmen adayı olması ayrı bir hassasiyeti de beraberinde getirmektedir. Bu açıdan YÖK 21. yüzyılın öğretmen adaylarından beklentilerini gerçekleştirebilmek için 2006 yılında eğitim fakülteleri müfredatlarında ciddi bir değişikliğe gitmiştir. Yeni programlarla, Avrupa Birliği Öğretmen Yetiştirme Raporundaki (EC, 2006), öğretmenlik mesleğinin profesyonelleşmesi ve profesyonel öğretmen yetiştirilmesi hedefi benimsenmiştir. Raporda profesyonel öğretmen; “öğretim, öğrenme ve 
çalışmaya ilişkin araştırma sonuçlarına dayalı bilgiyle yoğrulmuş; etkili öğretme, öğrenme ve çalışma süreçlerinin geliştirilmesi için zengin geçerli deneyimlere sahip; özerk, yetkin, öğrencileriyle ilgili, eleştirel yapısı gelişmiş, entelektüel; öğretmenlik mesleğiyle ilgili özerk meslek örgütlerinde sorumluluk alan; meslek etiğini benimsemiş kişiler" olarak tanımlanmıştır.

Görüldüğü üzere profesyonel öğretmen tanımlamasındaki özellik ve kabiliyetlere sahip olabilmek, okuma alışkanlığı ve kültürü edinmiş olmakla doğrudan ilişkilidir. Bu bağlamda öğrencileri tarafından model alınacak olan öğretmen adaylarının okuma alışkanlıklarının iyi düzeyde olması önem taşımaktadır. Bu sebeple nesil yetiştirecek öğretmen adaylarının okuma alışkanlıklarının tespit edilmesi önemlidir. Bu çalışmada, eğitim fakültesinde toplam 21 bölümde öğrenim gören öğretmen adaylarının okuma alışkanlıkları profilinin tespiti amaçlanmıştır.

Öğretmen adayları üzerinde yapılmış okumayla ilgili çalışmaların genelinin bir ya da en fazla iki bölüme odaklandığı ayrıca genellikle tek sınıf düzeyinde çalışıldığı belirlenmiştir. Eğitim Fakültesindeki bütün bölümleri kapsayan bir okuma alışkanlığı profili çalışması yoktur. Buradan hareketle araştırmanın amacı; Türkiye' de öğrenci sayısı en fazla Eğitim Fakültelerinden biri olan Necmettin Erbakan Üniversitesi, Ahmet Keleşoğlu Eğitim Fakültesindeki lisansı olan programların bütün sınıf düzeyleri üzerinde çalışma gerçekleştirilerek ilgili eğitim fakültesinin okuma alışkanlığı profilinin çıkarılması olarak belirlenmiştir. Bu sebeple öğrencilere "yılda okudukları kitap sayısı, okumalarında etkili olan unsurlar, okumalarına engel olan unsurlar, en çok okudukları kitap türleri, kitap okuma-internete girmeTV izleme-arkadaşlarıyla vakit geçirme süreleri, en çok okudukları materyaller ile en çok okunan ve etkilenilen yerli ve yabancı kitaplar" sorulmuştur.

\section{Yöntem}

\section{Araştırmanın Modeli}

$\mathrm{Bu}$ araştırma, eğitim fakültesi öğrencilerinin okuma alışkanlığı profillerini tespit etmeye yönelik bir çalışmadır. Araştırmada betimsel tarama modeli kullanılmıştır. Tarama modelleri, geçmişte ya da hâlen var olan bir durumu var olduğu şekliyle betimlemeyi amaçlayan araştırma yaklaşımlarıdır (Karasar, 2008: 77).

\section{Evren ve Örneklem}

Araştırmanın evrenini, Necmettin Erbakan Üniversitesi Ahmet Keleşoğlu Eğitim Fakültesinde öğrenim görmekte olan öğrenciler 
oluşturmaktadır. Örnekleme yöntemi olarak seçkisiz örnekleme yöntemlerinden tabakalı örnekleme yöntemi kullanılmıştır. Tabakalı örnekleme, evrendeki alt grupların belirlenip bunların evren büyüklügüü içindeki oranlarıyla örneklemde temsil edilmelerini sağlamayı amaçlayan bir örnekleme yöntemidir (Büyüköztürk vd., 2008). Bu amaçla, 2014-2015 eğitimöğretim yılında Almanca, Biyoloji, BÖTE, Coğrafya, Din, Kültür ve Ahlak Bilgisi, Fen Bilgisi, Fizik, İlköğretim Matematik, İngilizce, Kimya, Müzik, Okul Öncesi, Ortaöğretim Matematik, PDR, Resim, Sınıf, Sosyal Bilgiler, Tarih, Türk Dili ve Edebiyatı, Türkçe ve Zihin Engelliler Öğretmenliği bölümlerinden (21 bölüm) her sınıf düzeyinde 10'ar öğrenci (5 kız 5 erkek), toplamda bir bölümden $40^{\prime}$ ar olmak üzere 840 öğrenci araştırmanın örneklemini oluşturmaktadır. Ortaöğretim bölümlerine 2013-2014 eğitimöğretim yılında öğrenci alınmaması nedeniyle bu bölümlerdeki öğrenciler 1, 3,4 ve 5 . sinıf öğrencileridir.

\section{Veri Toplama Araci}

Okuma alışkanlığı profili çıkarmaya yönelik yapılan araştırmada, veri toplama aracı olarak araştırmacılar tarafından bir soru formu hazırlanmıştır. Soru formunun hazırlanma sürecinde, alan yazında yer alan ilgili çalışmalar taranmış ve alan uzmanlarının görüşü alınmıştır. Uygulama süreci başlatılmadan önce her bölümden 6 öğrenci olmak üzere toplamda 126 öğrenciye soru formunun pilot uygulaması yapılmıştır. Yapılan bu pilot çalışmanın ardından, soru formuna son şekli verilmiştir. Son hali ile soru formu iki bölümden oluşmaktadır. İlk bölümde demografik özelliklerle ilgili 7 soru; ikinci bölümde ise okuma alışkanlıklarını belirlemeye yönelik 10 soru yer almaktadır. Sorularda "diğer" seçeneğine de yer verilerek soru ile ilgili öğrencilerin açılayıcı bilgi yazmaları istenmiştir.

\section{Verilerin Analizi}

Verileri betimlemek için yüzde (\%) ve frekans (f) teknikleri kullanılmıştır. Sınıflar arası dağılım ve yüzdeleri ayrı bölümler hâlinde gösterilmiştir. Sayısal veriler, sınıflar arası dağılım esas alınarak yorumlanmıştır. Sınıflar arası dağılım ve yüzdelik gösterimle birinci sınıftan son sınıfa kadar olan süreçte öğrencilerin nasıl bir gelişim gösterdiği ortaya konulmaya çalışılmıştır.

\section{Bulgular}

Öğrencilerin bir yılda okudukları kitap sayısı, okumalarında etkili olan unsurlar, okumalarına engel olan unsurlar, en çok okudukları kitap türleri, kitap okuma-internete girme-TV izleme-arkadaşlarıly vakit geçirme 
süreleri, en çok okudukları materyaller ile en çok okunan ve etkilenilen yerli ve yabancı kitaplarla ilgili bulgular aşağıda tablolar halinde sunulmuştur.

Tablo 1. Eğitim Fakültesi Öğrencilerinin Bir Yılda Okudukları Kitap Sayısı

\begin{tabular}{|c|c|c|c|c|c|c|c|c|c|c|}
\hline \multirow[t]{2}{*}{ Bölümler } & \multicolumn{2}{|c|}{$\begin{array}{l}\text { Yilda } \\
\text { tan } \\
\text { Daha }\end{array}$} & \multicolumn{2}{|c|}{$\begin{array}{l}\text { Yilda } \\
\text { 11-15 }\end{array}$} & $\begin{array}{l}\text { Yilda } \\
6-10\end{array}$ & \multicolumn{2}{|c|}{$\begin{array}{l}\text { Yilda } \\
1-5\end{array}$} & \multicolumn{3}{|c|}{ Hiç Okumuyorum } \\
\hline & & $\%$ & $\mathrm{f}$ & $\%$ & $f$ & $\%$ & $f$ & $\%$ & $f$ & $\%$ \\
\hline Almanca & 5 & 12.5 & 4 & 10 & 26 & 65 & 3 & 7.5 & 2 & 5 \\
\hline Biyoloji & 1 & 2.5 & 10 & 25 & 7 & 17.5 & 14 & 35 & 8 & 20 \\
\hline BÖTE & 2 & 5 & 7 & 17.5 & 16 & 40 & 8 & 20 & 7 & 17.5 \\
\hline Coğrafya & 4 & 10 & 8 & 20 & 11 & 27.5 & 14 & 35 & 3 & 7.5 \\
\hline $\begin{array}{l}\text { Din } \\
\text { K.A.B }\end{array}$ & 8 & 20 & 17 & 42.5 & 9 & 22.5 & 4 & 10 & 2 & 5 \\
\hline Fen B. & 1 & 2.5 & 5 & 12.5 & 8 & 20 & 18 & 45 & 8 & 20 \\
\hline Fizik & 2 & 5 & 6 & 15 & 16 & 40 & 12 & 30 & 4 & 10 \\
\hline İlk. Mat. & 1 & 2.5 & 10 & 25 & 5 & 12.5 & 18 & 45 & 6 & 15 \\
\hline İngilizce & 4 & 10 & 7 & 17.5 & 17 & 42.5 & 10 & 25 & 2 & 5 \\
\hline Kimya & - & - & 2 & 5 & 12 & 30 & 20 & 50 & 6 & 15 \\
\hline Müzik & - & - & - & - & 7 & 17.5 & 25 & 62.5 & 8 & 20 \\
\hline Okul Ö . & 3 & 7.5 & 9 & 22.5 & 20 & 50 & 6 & 15 & 2 & 5 \\
\hline Ort. Mat & 2 & 5 & 8 & 20 & 19 & 47.5 & 6 & 15 & 5 & 12.5 \\
\hline PDR & 4 & 10 & 8 & 20 & 20 & 50 & 5 & 12.5 & 3 & 7.5 \\
\hline Resim & - & - & - & - & 8 & 20 & 22 & 55 & 10 & 25 \\
\hline Sinif & 2 & 5 & 8 & 20 & 10 & 25 & 13 & 32.5 & 7 & 17.5 \\
\hline Sosyal B. & 3 & 7.5 & 6 & 15 & 8 & 20 & 20 & 50 & 3 & 7.5 \\
\hline Tarih & 5 & 12.5 & 19 & 47.5 & 7 & 17.5 & 7 & 17.5 & 2 & 5 \\
\hline $\begin{array}{l}\text { Türk D. } \\
\text { E. }\end{array}$ & 8 & 20 & 26 & 65 & 4 & 10 & 2 & 5 & - & - \\
\hline Türkçe & 6 & 15 & 10 & 25 & 15 & 37.5 & 7 & 17.5 & 2 & 5 \\
\hline Zih. Eng & 2 & 5 & 2 & 5 & 8 & 20 & 18 & 45 & 10 & 25 \\
\hline
\end{tabular}

Tablo 1'deki bulgulara göre ağırlıklı olarak yılda bir-beş kitap okuyan bölümler Biyoloji, Coğrafya, Fen Bilgisi, İlköğretim Matematik, Kimya, Müzik, Resim, Sınıf Öğretmenliği Sosyal Bilgiler ve Zihin Engelliler Öğretmenliğidir. Ağırlıklı olarak 6-10 kitap okuyan bölümler Almanca, BÖTE, Fizik, İngilizce, Okul Öncesi, Ortaöğretim Matematik, PDR ve Türkçe Öğretmenliğidir. Ağırlıklı olarak 11-15 kitap okuyan bölümler Din Kültürü, Tarih ve Türk Dili ve Edebiyatı Öğretmenliğidir. Kimya Öğretmenliğinde 15 kitaptan, Müzik ve Resim Öğretmenliğinde 10 kitaptan fazla okuyan öğrenciye rastlanmamıştır. En fazla okuyanların Din Kültürü, Türk Dili ve 
Edebiyatı ve Tarih Öğretmenliğinde; "hiç okumuyorum" diyenlerin ise en fazla Zihin Engelliler ve Resim Öğretmenliğinde olduğu tespit edilmiştir.

Tablo 2. Eğitim Fakültesi Öğrencilerinin Okumalarında Etkili Olan Unsurlar

\begin{tabular}{|c|c|c|c|c|c|c|c|c|c|c|}
\hline \multirow[t]{2}{*}{ Bölümler } & \multicolumn{2}{|c|}{$\begin{array}{l}\text { Arkadaş } \\
\text { tavsiyesi }\end{array}$} & \multicolumn{2}{|c|}{$\begin{array}{c}\text { Kitaba } \\
\text { kütüphanede } \\
\text { rastlama }\end{array}$} & \multicolumn{2}{|c|}{$\begin{array}{c}\text { Kişisel } \\
\text { Tercihleri- } \\
\text { konuya ilgi } \\
\text { duyma }\end{array}$} & \multicolumn{2}{|c|}{ Yazar } & \multicolumn{2}{|c|}{$\begin{array}{l}\text { Hocalarının } \\
\text { tavsiyesi }\end{array}$} \\
\hline & $\mathbf{f}$ & $\%$ & $\mathbf{f}$ & $\%$ & $\mathbf{f}$ & $\%$ & $\mathbf{f}$ & $\%$ & $\mathbf{f}$ & $\%$ \\
\hline Almanca & 21 & 52.5 & 4 & 10 & 4 & 10 & 6 & 15 & 5 & 12.5 \\
\hline Biyoloji & 24 & 60 & 5 & 12.5 & 7 & 17.5 & 4 & 10 & & \\
\hline ВÖTE & 21 & 52.5 & 6 & 15 & 6 & 15 & 7 & 17.5 & & \\
\hline Coğrafya & 19 & 47.5 & 9 & 22.5 & 7 & 17.5 & 5 & 12.5 & & \\
\hline Din & 11 & 27.5 & & & 6 & 15 & 6 & 15 & 17 & 42.5 \\
\hline Fen B. & 16 & 40 & 3 & 7.5 & 2 & 5 & 14 & 35 & 5 & 12.5 \\
\hline Fizik & 23 & 57.5 & 4 & 10 & 7 & 17.5 & 6 & 15 & & \\
\hline İlk. Mat. & 23 & $\mathbf{5 7 . 5}$ & 6 & 15 & 5 & 12.5 & 6 & 15 & & \\
\hline İngilizce & 20 & 50 & 6 & 15 & 8 & 20 & 4 & 10 & 2 & 5 \\
\hline Kimya & 19 & 47.5 & 7 & 17.5 & 10 & 25 & 4 & 10 & & \\
\hline Müzik & 24 & 60 & 6 & 15 & 4 & 10 & 4 & 10 & 2 & 5 \\
\hline Okul Ö . & 27 & 67.5 & 4 & 10 & 6 & 15 & 3 & 7.5 & & \\
\hline Ort. Mat & 13 & 32.5 & 5 & 12.5 & 8 & 20 & 8 & 20 & 6 & 15 \\
\hline PDR & 19 & 47.5 & 11 & 27.5 & 3 & 7.5 & 7 & 17.5 & & \\
\hline Resim & 22 & 55 & 6 & 15 & 6 & 15 & 6 & 15 & & \\
\hline Sinıf & 18 & 45 & 10 & 25 & 6 & 15 & 6 & 15 & & \\
\hline Sosyal B. & 20 & 50 & 7 & 17.5 & 4 & 10 & 3 & 7.5 & 6 & 15 \\
\hline Tarih & 13 & 32.5 & 7 & 17.5 & 3 & 7.5 & 3 & 7.5 & 14 & 35 \\
\hline Türk Dili & 8 & 20 & 3 & 7.5 & 8 & 20 & 4 & 10 & 17 & 42.5 \\
\hline Türkçe & 14 & 35 & 13 & 32.5 & 7 & 17.5 & 6 & 15 & & \\
\hline Zih. Eng & 23 & 57.5 & 6 & 15 & 5 & 12.5 & 4 & 10 & 2 & 5 \\
\hline
\end{tabular}

Tablo 2'deki bulgulardan hareketle bölümlere göre öğrencilerin okumalarında etkili olan unsurlarda; Almanca, Biyoloji, BÖTE, Coğrafya, Fen Bilgisi, Fizik, İlköğretim Matematik, İngilizce, Kimya, Müzik, Okul Öncesi, Ortaöğretim Matematik, PDR, Resim, Sınıf, Sosyal Bilgiler, Türkçe, Zihin Engelliler Öğretmenliği bölümlerinde ilk sırada "arkadaş tavsiyesi" yer almaktadır. Din Kültürü, Tarih ve Türk Dili ve Edebiyatı Öğretmenliği bölümlerinde ilk sırada "hocalarımın tavsiyesi" yer almaktadır. "Kişisel tercihler (ilgi duyma)" en çok Kimya Öğretmenliğinde, "yazar" ise Fen Bilgisi Öğretmenliğinde daha etkilidir. 
Tablo 3. Eğitim Fakültesi Öğrencilerinin Okumalarına Engel Olan Unsurlar

\begin{tabular}{|c|c|c|c|c|c|c|c|c|c|c|}
\hline \multirow[t]{3}{*}{ Bölümler } & \multicolumn{2}{|c|}{$\begin{array}{l}\text { Derslerin } \\
\text { Yoğunluğ } \\
\mathbf{u}\end{array}$} & \multicolumn{2}{|c|}{$\begin{array}{l}\text { Arkadaşlarla } \\
\text { vakit geçirme }\end{array}$} & \multicolumn{2}{|c|}{$\begin{array}{l}\text { Okuma } \\
\text { Alışkanlığını } \\
\text { n Olmaması }\end{array}$} & \multicolumn{2}{|c|}{$\begin{array}{l}\text { Bilgisayar } \\
\text { ve } \\
\text { İnternet } \\
\text { Kullanma }\end{array}$} & \multicolumn{2}{|c|}{$\begin{array}{l}\text { KPSS'ye } \\
\text { Hazırlanma }\end{array}$} \\
\hline & \multirow[b]{2}{*}{ f } & \multirow[b]{2}{*}{$\%$} & \multirow[b]{2}{*}{$\mathbf{f}$} & \multirow[b]{2}{*}{$\%$} & \multirow[b]{2}{*}{ f } & \multirow[b]{2}{*}{$\%$} & \multicolumn{2}{|c|}{$\begin{array}{l}\mathbf{k} \quad \mathrm{TV} \\
\text { İzlemek }\end{array}$} & \multirow[b]{2}{*}{$\mathbf{f}$} & \multirow[b]{2}{*}{$\%$} \\
\hline & & & & & & & $\mathbf{f}$ & $\%$ & & \\
\hline Almanca & 9 & 22.5 & 20 & 50 & 2 & 5 & 4 & 10 & 5 & 12.5 \\
\hline Biyoloji & 5 & 12.5 & 15 & 37.5 & 11 & 27.5 & 6 & 15 & 3 & 7.5 \\
\hline \multirow[t]{2}{*}{ BÖTE } & 8 & 20 & 4 & 10 & 11 & 27.5 & 1 & 37.5 & 2 & 5 \\
\hline & & & & & & & 5 & & & \\
\hline \multirow[t]{2}{*}{ Coğrafya } & 10 & 25 & 6 & 15 & 12 & 30 & 1 & 25 & 2 & 5 \\
\hline & & & & & & & 0 & & & \\
\hline \multirow[t]{2}{*}{ Din } & 14 & 35 & 13 & 32.5 & - & & 1 & 27.5 & 2 & 5 \\
\hline & & & & & & & 1 & & & \\
\hline Fen B. & 8 & 20 & 6 & 15 & 14 & 35 & 8 & 20 & 4 & 10 \\
\hline Fizik & 11 & 27.5 & 12 & 30 & 13 & 32.5 & 2 & 5 & 2 & 5 \\
\hline \multirow[t]{2}{*}{ İlk. Mat. } & 10 & 25 & 5 & 12.5 & 5 & 12.5 & 1 & 35 & 6 & 15 \\
\hline & & & & & & & 4 & & & \\
\hline \multirow[t]{2}{*}{ İngilizce } & 6 & 15 & 6 & 15 & 15 & 37.5 & 1 & 25 & 3 & 7.5 \\
\hline & & & & & & & 0 & & & \\
\hline \multirow[t]{2}{*}{ Kimya } & 11 & 27.5 & 4 & 10 & 15 & 37.5 & & 15 & 4 & 10 \\
\hline & & & & & & & 6 & & & \\
\hline \multirow[t]{2}{*}{ Müzik } & - & - & 13 & 32.5 & 12 & 30 & 1 & 30 & 3 & 7.5 \\
\hline & & & & & & & 2 & & & \\
\hline \multirow[t]{2}{*}{ Okul Ö . } & 5 & 12.5 & 6 & 15 & 10 & 25 & 1 & 32.5 & 6 & 15 \\
\hline & & & & & & & 3 & & & \\
\hline Ort. Mat & 10 & 25 & 8 & 20 & 11 & 27.5 & 5 & 12.5 & 5 & 12.5 \\
\hline PDR & 6 & 15 & 15 & 37.5 & 9 & 22.5 & 5 & 12.5 & 6 & 15 \\
\hline Resim & 17 & 42.5 & 4 & 10 & 10 & 25 & 6 & 15 & 3 & 7.5 \\
\hline Sinif & 11 & 27.5 & 8 & 20 & 13 & 32.5 & 4 & 10 & 4 & 10 \\
\hline \multirow[t]{2}{*}{ Sosyal B. } & 11 & & 6 & 15 & 13 & 32.5 & 6 & 15 & 4 & 10 \\
\hline & & 27.5 & & & & & & & & \\
\hline Tarih & 19 & 47.5 & 10 & 25 & 3 & 7.5 & 5 & 12.5 & 3 & 7.5 \\
\hline Türk Dili & 14 & 35 & 8 & 20 & 7 & 17.5 & 9 & 22.5 & 2 & 5 \\
\hline Türkçe & 9 & 22.5 & 13 & 32.5 & 6 & 15 & 9 & 22.5 & 3 & 7.5 \\
\hline Zih. Eng & 11 & 27.5 & 4 & 10 & 13 & 32.5 & 8 & 20 & 4 & 10 \\
\hline
\end{tabular}

Tablo 3'teki bulgulara göre öğrencilerin okumalarına engel olan unsurlar arasında Coğrafya, Fen Bilgisi, Fizik, İngilizce, Kimya, Ortaöğretim 
Matematik, Sınıf, Sosyal Bilgiler ve Zihin Engelliler Öğretmenliği olmak üzere dokuz bölümde ilk sırada "Okuma Alışkanlığımın Olmaması"; Almanca, Biyoloji, Müzik, PDR ve Türkçe Öğretmenliği olmak üzere beş bölümde ilk sırada "Arkadaşlarımla vakit geçirmek"; Din Kültür ve A.B., Resim, Tarih, Türk Dili ve Edebiyatı olmak üzere dört bölümde ilk sırada "derslerin yoğunluğu"; BÖTE, İlköğretim Matematik, Okul Öncesi Öğretmenliği olmak üzere üç bölümde "bilgisayar ve internet kullanmak" seçilmiştir.

Tablo 4. Eğitim Fakültesi Öğrencilerinin Okuma, İnternet Kullanma, TV İzleme ve Arkadaşlarıyla Vakit Geçirme Süreleri

\begin{tabular}{|c|c|c|c|c|c|c|c|c|c|c|c|c|}
\hline \multirow[t]{2}{*}{ Bölümler } & \multicolumn{3}{|c|}{ Okuma } & \multicolumn{3}{|c|}{ İnternet } & \multicolumn{3}{|c|}{ TV } & \multicolumn{3}{|c|}{$\begin{array}{l}\text { Arkadaşlarla } \\
\text { vakit geçirme }\end{array}$} \\
\hline & f & $\%$ & Süre & f & $\%$ & Süre & f & $\%$ & Süre & f & $\%$ & Süre \\
\hline Almanca & 24 & 60 & $\begin{array}{l}1-2 \\
\text { saat }\end{array}$ & 21 & 52.5 & $\begin{array}{l}1 \\
\text { Saatten } \\
\text { Az }\end{array}$ & 20 & 50 & $\begin{array}{l}1 \\
\text { Saatten } \\
\mathrm{Az}\end{array}$ & 16 & 40 & $\begin{array}{l}3-4 \\
\text { saat }\end{array}$ \\
\hline Biyoloji & 15 & 37.5 & $\begin{array}{l}1 \\
\text { Saatten } \\
\mathrm{Az}\end{array}$ & 19 & 47.5 & $\begin{array}{l}1 \\
\text { Saatten } \\
\text { Az }\end{array}$ & 16 & 40 & $\begin{array}{l}1 \\
\text { Saatten } \\
\text { Az }\end{array}$ & 21 & 52.5 & $\begin{array}{l}2-3 \\
\text { saat }\end{array}$ \\
\hline ВÖTE & 16 & 40 & $\begin{array}{l}1 \\
\text { Saatten } \\
\mathrm{Az}\end{array}$ & 26 & 65 & $\begin{array}{l}3-4 \\
\text { saat }\end{array}$ & 18 & 45 & - & 18 & 45 & $\begin{array}{l}2-3 \\
\text { saat }\end{array}$ \\
\hline Coğrafya & 19 & 47.5 & $\begin{array}{l}1-2 \\
\text { saat }\end{array}$ & 18 & 45 & $\begin{array}{l}2-3 \\
\text { saat }\end{array}$ & 14 & 35 & $\begin{array}{l}3-4 \\
\text { saat }\end{array}$ & 24 & 60 & $\begin{array}{l}1-2 \\
\text { saat }\end{array}$ \\
\hline Din & 23 & 57.5 & $\begin{array}{l}2-3 \\
\text { saat }\end{array}$ & 23 & 57.5 & $\begin{array}{l}1-2 \\
\text { saat }\end{array}$ & 17 & 42.5 & $\begin{array}{l}3-4 \\
\text { saat }\end{array}$ & 23 & 57.5 & $\begin{array}{l}1-2 \\
\text { saat }\end{array}$ \\
\hline Fen $B$. & 16 & 40 & $\begin{array}{l}1 \\
\text { Saatten } \\
\mathrm{Az}\end{array}$ & 21 & 52.5 & $\begin{array}{l}3-4 \\
\text { saat }\end{array}$ & 16 & 40 & $\begin{array}{l}1-2 \\
\text { saat }\end{array}$ & 22 & 55 & $\begin{array}{l}3-4 \\
\text { saat }\end{array}$ \\
\hline Fizik & 20 & 50 & $\begin{array}{l}1 \\
\text { Saatten } \\
\mathrm{Az}\end{array}$ & 16 & 40 & $\begin{array}{l}1-2 \\
\text { saat }\end{array}$ & 15 & 37.5 & $\begin{array}{l}1-2 \\
\text { saat }\end{array}$ & 20 & 50 & $\begin{array}{l}3-4 \\
\text { saat }\end{array}$ \\
\hline İlk. Mat. & 20 & 50 & $\begin{array}{l}1 \\
\text { Saatten } \\
\mathrm{Az}\end{array}$ & 18 & 45 & $\begin{array}{l}3-4 \\
\text { saat }\end{array}$ & 18 & 45 & $\begin{array}{l}2-3 \\
\text { saat }\end{array}$ & 17 & 42.5 & $\begin{array}{l}3-4 \\
\text { saat }\end{array}$ \\
\hline İngilizce & 22 & 55 & $\begin{array}{l}1-2 \\
\text { saat }\end{array}$ & 19 & 47.5 & $\begin{array}{l}1 \\
\text { Saatten } \\
\text { Az }\end{array}$ & 14 & 35 & $\begin{array}{l}1 \\
\text { Saatten } \\
\text { Az }\end{array}$ & 14 & 35 & $\begin{array}{l}2-3 \\
\text { saat }\end{array}$ \\
\hline Kimya & 17 & 42.5 & $\begin{array}{l}1 \\
\text { Saatten } \\
\mathrm{Az}\end{array}$ & 17 & 42.5 & $\begin{array}{l}1 \\
\text { Saatten } \\
\text { Az }\end{array}$ & 14 & 35 & $\begin{array}{l}1-2 \\
\text { saat }\end{array}$ & 18 & 45 & $\begin{array}{l}3-4 \\
\text { saat }\end{array}$ \\
\hline Müzik & 26 & 62.5 & $\begin{array}{l}1 \\
\text { Saatten } \\
\mathrm{Az}\end{array}$ & 26 & 65 & $\begin{array}{l}2-3 \\
\text { saat }\end{array}$ & 26 & 65 & $\begin{array}{l}1-2 \\
\text { saat }\end{array}$ & 21 & 52.5 & $\begin{array}{l}3-4 \\
\text { saat }\end{array}$ \\
\hline
\end{tabular}




\begin{tabular}{|c|c|c|c|c|c|c|c|c|c|c|c|c|}
\hline Okul Ö . & 21 & 52.5 & $\begin{array}{l}1 \\
\text { Saatten } \\
\mathrm{Az}\end{array}$ & 25 & 62.5 & $\begin{array}{l}3-4 \\
\text { saat }\end{array}$ & 17 & 42.5 & $\begin{array}{l}2-3 \\
\text { saat }\end{array}$ & 25 & 62.5 & $\begin{array}{l}2-3 \\
\text { saat }\end{array}$ \\
\hline Ort. Mat & 25 & 62.5 & $\begin{array}{l}1 \\
\text { Saatten } \\
\mathrm{Az}\end{array}$ & 26 & 65 & $\begin{array}{l}2-3 \\
\text { saat }\end{array}$ & 14 & 35 & $\begin{array}{l}2-3 \\
\text { saat }\end{array}$ & 25 & 62.5 & $\begin{array}{l}2-3 \\
\text { saat }\end{array}$ \\
\hline PDR & 17 & 42.5 & $\begin{array}{l}1 \\
\text { Saatten } \\
\mathrm{Az}\end{array}$ & 18 & 45 & $\begin{array}{l}1 \\
\text { Saatten } \\
\text { Az }\end{array}$ & 17 & 42.5 & $\begin{array}{l}2-3 \\
\text { saat }\end{array}$ & 19 & 47.5 & $\begin{array}{l}2-3 \\
\text { saat }\end{array}$ \\
\hline Resim & 26 & 65 & $\begin{array}{l}1 \\
\text { Saatten } \\
\mathrm{Az}\end{array}$ & 18 & 45 & $\begin{array}{l}3-4 \\
\text { saat }\end{array}$ & 15 & 37.5 & - & 14 & 35 & $\begin{array}{l}3-4 \\
\text { saat }\end{array}$ \\
\hline Sinif & 19 & 47.5 & $\begin{array}{l}1 \\
\text { Saatten } \\
\mathrm{Az}\end{array}$ & 19 & 47.5 & $\begin{array}{l}2-3 \\
\text { saat }\end{array}$ & 16 & 40 & $\begin{array}{l}1 \\
\text { Saatten } \\
\mathrm{Az}\end{array}$ & 15 & 37.5 & $\begin{array}{l}2-3 \\
\text { saat }\end{array}$ \\
\hline Sosyal B. & 17 & 42.5 & $\begin{array}{l}1-2 \\
\text { saat }\end{array}$ & 23 & 57.5 & $\begin{array}{l}2-3 \\
\text { saat }\end{array}$ & 17 & 42.5 & $\begin{array}{l}3-4 \\
\text { saat }\end{array}$ & 16 & 40 & $\begin{array}{l}2- \\
\text { 3saat }\end{array}$ \\
\hline Tarih & 18 & 45 & $\begin{array}{l}2-3 \\
\text { saat }\end{array}$ & 19 & 47.5 & $\begin{array}{l}1 \\
\text { Saatten } \\
\text { Az }\end{array}$ & 16 & 40 & - & 14 & 35 & $\begin{array}{l}1-2 \\
\text { saat }\end{array}$ \\
\hline $\begin{array}{l}\text { Türk } \\
\text { Dili }\end{array}$ & 22 & 55 & $\begin{array}{l}3-4 \\
\text { saat }\end{array}$ & 16 & 40 & $\begin{array}{l}1 \\
\text { Saatten } \\
\text { Az }\end{array}$ & 14 & 35 & $\begin{array}{l}1 \\
\text { Saatten } \\
\mathrm{Az}\end{array}$ & 19 & 47.5 & $\begin{array}{l}2-3 \\
\text { saat }\end{array}$ \\
\hline Türkçe & 21 & 52.5 & $\begin{array}{l}2-3 \\
\text { saat }\end{array}$ & 20 & 50 & $\begin{array}{l}1 \\
\text { Saatten } \\
\text { Az }\end{array}$ & 18 & 45 & $\begin{array}{l}1 \\
\text { Saatten } \\
\mathrm{Az}\end{array}$ & 14 & 35 & $\begin{array}{l}3-4 \\
\text { saat }\end{array}$ \\
\hline Zih. Eng & 23 & 57.5 & $\begin{array}{l}1 \\
\text { Saatten } \\
\mathrm{Az}\end{array}$ & 15 & 37.5 & $\begin{array}{l}2-3 \\
\text { saat }\end{array}$ & 14 & 35 & $\begin{array}{l}1 \\
\text { Saatten } \\
\mathrm{Az}\end{array}$ & 22 & 55 & $\begin{array}{l}2-3 \\
\text { saat }\end{array}$ \\
\hline
\end{tabular}

Tablo 4'deki bulgulara göre Biyoloji, BÖTE, Fen Bilgisi, Fizik, İlköğretim Matematik, Kimya, Müzik, Okul Öncesi, Ortaöğretim Matematik, PDR, Resim, Sınıf ve Zihin Engelliler Öğretmenliği bölümlerinde öğretmen adayları genel olarak 1 saatten az okumaktadırlar. Öğretmen adayları, Almanca, Coğrafya, İngilizce ve Sosyal Bilgiler Öğretmenliği bölümlerinde 12 saat; Tarih ve Türkçe Din Kültürü Öğretmenliği bölümlerinde 2-3 saat; Türk Dili ve Edebiyatı Öğretmenliğinde 3-4 saat okuduklarını belirmişlerdir.

Almanca, Biyoloji, İngilizce, Kimya, PDR, Tarih, Türk Dili ve Edebiyatı ve Türkçe Öğretmenliği bölümlerinde öğrenciler 1 saatten az; Din Kültürü ve Fizik bölümlerinde öğrenciler 1-2 saat; Coğrafya, Müzik, Ortaöğretim Matematik, Sınıf, Sosyal Bilgiler, Zihin Engelliler Öğretmenliği bölümlerinde öğrenciler 2-3 saat; BÖTE, Fen Bilgisi, İlköğretim Matematik, Okul öncesi ve Resim Öğretmenliği bölümlerinde öğrenciler 3-4 saat internete girmektedirler. 
BÖTE, Resim ve Tarih Öğretmenliği bölümlerinde öğrenciler hiç TV izlemediklerini belirtmişlerdir. Almanca, Biyoloji, İngilizce, Sınıf, Türk Dili ve Edebiyatı, Türkçe ve Zihin Engelliler Öğretmenliği bölümlerinde öğrenciler 1 saatten az; Fen Bilgisi, Fizik, Kimya ve Müzik Öğretmenliği bölümlerinde öğrenciler 1-2 saat; İlköğretim Matematik, Okul Öncesi ve Ortaöğretim Matematik Öğretmenliği, PDR bölümlerinde öğrenciler 2-3 saat; Coğrafya, Din Kültürü ve Sosyal Bilgiler Öğretmenliği bölümlerinde ise 3-4 saat TV izlemektedirler.

Coğrafya, Din Kültürü ve Tarih Öğretmenliği bölümlerinde öğrenciler 1-2 saat; Biyoloji, BÖTE, İngilizce, Okul Öncesi, Ortaöğretim Matematik, PDR, Sınıf, Sosyal Bilgiler, Türk Dili ve Edebiyatı ve Zihin Engelliler Öğretmenliği bölümlerinde öğrenciler 2-3 saat; Almanca, Fen, Fizik, İlköğretim Matematik, Kimya, Müzik, Resim ve Türkçe Öğretmenliği bölümlerinde öğrenciler 3-4 saat arkadaşlarıyla vakit geçirdiklerini söylemişlerdir. Ağırlıklı olarak bölümlerde okumanın, internetin ve TV'nin 1 saatten az, arkadaşlarla vakit geçirmenin 2- 3 saat olduğu görülmüştür.

Tablo 5. Eğitim Fakültesi Öğrencilerinin Okumalarında Tercih Ettikleri Materyaller

\begin{tabular}{|c|c|c|c|c|c|c|c|c|}
\hline \multirow[t]{2}{*}{ Bölümler } & \multicolumn{2}{|c|}{$\begin{array}{l}\text { İnternetteki } \\
\text { Gazeteler }\end{array}$} & \multicolumn{2}{|c|}{$\begin{array}{l}\text { Sosyal } \\
\text { Paylaşım } \\
\text { Sitelerindeki } \\
\text { Yazilar }\end{array}$} & \multicolumn{2}{|c|}{$\begin{array}{l}\text { Edebi } \\
\text { Kitaplar }\end{array}$} & \multicolumn{2}{|c|}{ Dergiler } \\
\hline & $\mathrm{f}$ & $\%$ & $\mathbf{f}$ & $\%$ & $\mathrm{f}$ & $\%$ & $\mathrm{f}$ & $\%$ \\
\hline Almanca & 10 & 25 & 14 & 35 & 10 & 25 & 6 & 15 \\
\hline Biyoloji & 11 & 27.5 & 13 & 32.5 & 11 & 27.5 & 5 & 12.5 \\
\hline ВÖTE & 15 & 37.5 & 17 & 42.5 & 4 & 10 & 4 & 10 \\
\hline Coğrafya & 9 & 22.5 & 12 & 30 & 14 & 35 & 5 & 12.5 \\
\hline Din & 8 & 20 & 12 & 30 & 13 & 32.5 & 7 & 17.5 \\
\hline Fen B. & 12 & 30 & 16 & 40 & 6 & 15 & 6 & 15 \\
\hline Fizik & 13 & 32.5 & 16 & 40 & 6 & 15 & 5 & 12.5 \\
\hline İlk. Mat. & 11 & 27.5 & 17 & 42.5 & 7 & 17.5 & 5 & 12.5 \\
\hline İngilizce & 10 & 25 & 13 & 32.5 & 11 & 27.5 & 6 & 15 \\
\hline Kimya & 14 & 35 & 15 & 37.5 & 7 & 17.5 & 4 & 10 \\
\hline Müzik & 10 & 25 & 16 & 40 & 6 & 15 & 8 & 20 \\
\hline Okul Ö. & 10 & 25 & 16 & 40 & 9 & 22.5 & 5 & 12.5 \\
\hline Ort. Mat & 13 & 32.5 & 18 & 45 & 5 & 12.5 & 4 & 10 \\
\hline PDR & 10 & 25 & 17 & 42.5 & 8 & 20 & 5 & 12.5 \\
\hline Resim & 9 & 22.5 & 17 & 42.5 & 4 & 10 & 10 & 25 \\
\hline Sinif & 10 & 25 & 15 & 37.5 & 8 & 20 & 7 & 17.5 \\
\hline
\end{tabular}




\begin{tabular}{lllllllll}
\hline Sosyal B. & 11 & 27.5 & $\mathbf{1 2}$ & $\mathbf{3 0}$ & 9 & 22.5 & 8 & 20 \\
Tarih & 10 & 25 & $\mathbf{1 1}$ & $\mathbf{2 7 . 5}$ & $\mathbf{1 1}$ & $\mathbf{2 7 . 5}$ & 8 & 20 \\
Türk Dili & 8 & 20 & 11 & 27.5 & $\mathbf{1 3}$ & $\mathbf{3 2 . 5}$ & 8 & 20 \\
Türkçe & 7 & 17.5 & 11 & 27.5 & $\mathbf{1 3}$ & $\mathbf{3 2 . 5}$ & 9 & 22.5 \\
Zih. Eng & 7 & 17.5 & $\mathbf{1 7}$ & $\mathbf{4 2 . 5}$ & 9 & 22.5 & 7 & 17.5 \\
\hline
\end{tabular}

Tablo 5'teki bulgulara göre bütün bölümlerde en çok tercih edilen materyaller arasında ilk dörtte edebî kitaplar, internet ortamındaki gazeteler, sosyal paylaşım sitelerindeki yazılar ve dinî dergiler yer almıştır. Öğrencilerin ağırlıklı olarak edebî kitap tercih ettikleri, alanlarındaki bilimsel kitapların bütün bölümlerde çok az öğrenci tarafından tercih edildiği görülmüştür. Gazetenin genellikle internet üzerinden okunduğu ve öğrencilerin güncel olayları takip ettikleri belirlenmiştir. Öğrencilerin büyük çoğunluğunun alanıyla ilgili bilimsel bir dergi okumadığı belirlenmiştir. Sadece resim ve tarih bölümünde bilimsel dergi okunmaktadır. Diğer bölümlerde dinî dergiler ağırlıktadır. Gazete dışında internette okunan yazılarda ise ilk sırada sosyal paylaşım sitelerindeki (özellikle Facebook ve Twitter) yazılar gelmektedir.

Almanca, Biyoloji, BÖTE, Fen Bilgisi, Fizik, İlköğretim Matematik, İngilizce, Kimya, Müzik, Okul öncesi, Ortaöğretim Matematik, PDR, Resim, Sınıf, Sosyal Bilgiler, Tarih ve Zihinsel Engelliler bölümlerindeki öğrenciler ilk sırada internet sitelerindeki yazıları okumaktadırlar. Coğrafya, Din Kültürü, Tarih, Türk Dili ve Edebiyatı ve Türkçe Öğretmenliği bölümlerindeki öğrenciler ilk sırada kitap okumayı seçmişlerdir.

En fazla derginin okunduğu bölüm Resimdir. Bu dergilerin ağırlıklı olarak "Sanart" ve "Artist" "Level" dergileri görülmektedir. Ancak bütün bölümlerde ağırlıklı olarak dinî dergilerin (Sızıntı, Yeni Ümit, Yağmur, Yeni Bahar, Genç Yaklaşım, Genç Beyin, Aksiyon, Zafer, Semerkand Aile, Bütün Dünya) okunduğu tespit edilmiştir. Müzik ve Resim Öğretmenliği bölümlerinde "Cosmopolitan, Marie Claire, Elle, Kültür Sanat" dergileri okunmaktadır. Tarih bölümündekiler genel olarak "Tv Tarih ve Atlas" dergilerine abonedirler. "National Geography, Bilim ve Teknik" dergileri de Zihin Engelliler Öğretmenliğinde okunmaktadır. İngilizce Öğretmenliğinde "Uykusuz" ve "Penguen" dergileri okunmaktadır. 
Sosyal Bilimler Dergisi 155

Tablo 6. Eğitim Fakültesi Öğrencilerinin Tercih Ettikleri Kitap Türleri

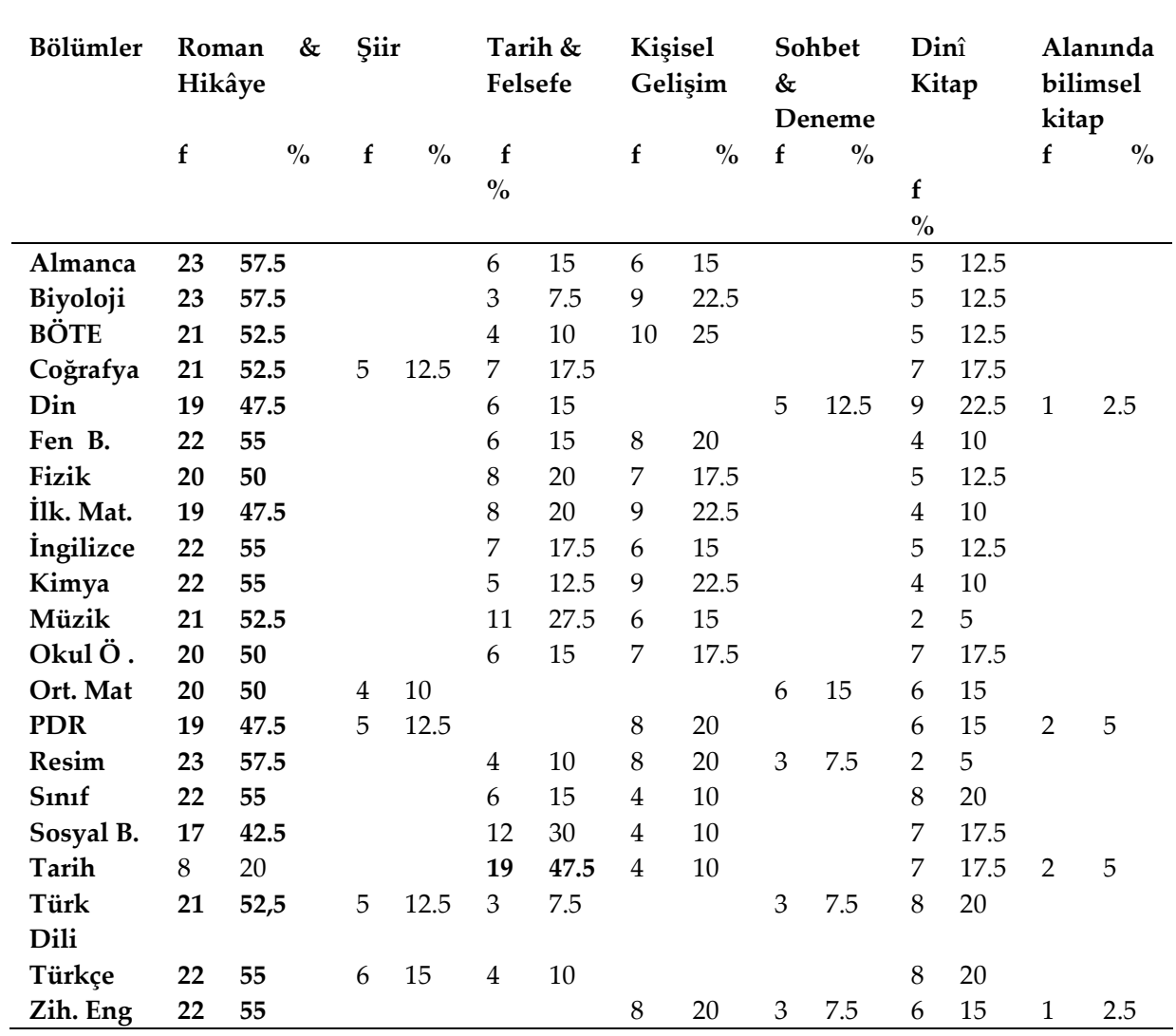

Tablo 6'daki bulgulardan hareketle bölümlere göre öğrencilerin en çok tercih ettikleri kitap türleri arasında ilk sırada roman ve hikâye yer almaktadır: Almanca, Biyoloji, BÖTE, Coğrafya, Din, Fen Bilgisi, Fizik, İlköğretim Matematik, İngilizce, Kimya, Müzik, Okul Öncesi, Ortaöğretim Matematik, PDR, Resim, Sınıf, Sosyal Bilgiler, Türk Dili ve Edebiyatı, Türkçe, Zihin Engellilerdir. Tarih ve felsefe en çok tarih bölümünde Tarih Öğretmenliğinde okunmaktadır. 10 bölümde (Almanca, Biyoloji, BÖTE, Fen Bilgisi, İlköğretim Matematik, Kimya, Okul Öncesi, PDR, Resim, Zihin Engelliler Öğretmenliği); en çok tercih edilen ikinci kitap türü kişisel gelişimdir. 7 bölümde (Coğrafya, Din Kültürü, Okul Öncesi, Ortaöğretim Matematik, Sınıf, Türk Dili, Türkçe) en çok tercih edilen ikinci kitap türü dinî kitaplardır. 5 bölümde (Coğrafya, Fizik, İngilizce, Müzik, Sosyal Bilgiler) en çok tercih edilen ikinci kitap türü tarih-felsefe kitaplarıdır. Tarih bölümünde ikinci sırada roman türü vardır. Ortaöğretim Matematik ikinci sırada dinî ve 
sohbet-deneme, Okul Öncesinde kişisel gelişim ve dinî, Coğrafyada tarih ve dinî kitaplar aynı orana sahip olarak 2. sıradadırlar. Şiiri ilk sıraya yazan bölümler Coğrafya, Ortaöğretim Matematik, PDR, Türk Dili ve Edebiyatı ve Türkçe Öğretmenliğidir. Sohbet-denemeyi ilk seçeneğe yazan bölümler Din Kültürü, Ortaöğretim Matematik, Resim, Türk Dili ve Edebiyatı, Zihin Engellilerdir. Coğrafya, Din Kültürü ve Ahlak Bilgisi, Ortaöğretim Matematik, Türk Dili ve Edebiyatı ve Türkçe Öğretmenliği bölümlerinde kişisel gelişim 1. Sıraya yazılmamıştır. Kişisel gelişimin oranının en fazla olduğu bölüm BÖTE' dir. Dinî kitabın en fazla olduğu bölüm Din Kültürüdür. Ortaöğretim Matematik, PDR ve Zihin Engelliler de tarih-felsefe 1. Sıraya yazılmamıştır. Alanında bilimsel kitap Din Kültürü, PDR, Tarih ve Zihin Engelliler Öğretmenliğinde seçilmiştir. Roman-hikâye ve dinî kitap her bölümde vardır.

Tablo 7. Eğitim Fakültesi Öğrencilerinin En Çok Okudukları Yerli ve Yabancı Kitaplar

\begin{tabular}{|c|c|c|c|c|c|c|}
\hline $\begin{array}{lll}\text { En Çok } & \text { Okunan } & \text { Yerli } \\
\text { Kitaplar } & & \\
\end{array}$ & $f$ & $\%$ & $\begin{array}{l}\text { En Çok Okunan } \\
\text { Kitaplar }\end{array}$ & Yabanc1 & $\mathbf{f}$ & $\%$ \\
\hline Ustam ve Ben (Elif Şafak) & 172 & 20,4 & $\begin{array}{l}\text { Uçurtma Avcısı } \\
\text { Hosseini) }\end{array}$ & (Khaled & 78 & 9,2 \\
\hline $\begin{array}{l}\text { Aşkın } 7 \text { Hali-Bişnev (Sinan } \\
\text { Yağmur) }\end{array}$ & 165 & 19,6 & Olasilıksız (Adam & Fewer) & 67 & 7,9 \\
\hline Mihmandar (İskender Pala) & 123 & 14,6 & $\begin{array}{l}\text { Beyaz Gemi } \\
\text { Aytmatov) }\end{array}$ & Tengiz & 55 & 6,5 \\
\hline
\end{tabular}

Tablo 7'ye göre eğitim fakültesi öğrencilerinin en çok okuduğu yerli kitaplar, "Ustam ve Ben, Aşkın 7 Hali-Bişnev ve Mihmandar"dır. Eğitim Fakültesi öğrencilerinin en çok okuduğu yabancı kitaplar, "Uçurtma Avcısı, Olasilıksız ve Beyaz Gemi"dir.

Tablo 8. Eğitim Fakültesi Öğrencilerinin En Çok Etkilendikleri Yerli ve Yabancı Kitaplar

\begin{tabular}{|c|c|c|c|c|c|c|}
\hline $\begin{array}{l}\text { En Çok Etkilenilen } \\
\text { Kitaplar }\end{array}$ & Yerli & f & $\%$ & $\begin{array}{l}\text { En Çok Etkilenilen Yabancı } \\
\text { Kitaplar }\end{array}$ & f & $\%$ \\
\hline Aşk (Elif Şafak) & & 125 & 14,8 & $\begin{array}{lll}\text { Uçurtma Avcısı } & \text { (Khaled } \\
\text { Hosseini) } & & \end{array}$ & 91 & 10,8 \\
\hline Piraye (Canan Tan) & & 98 & 11,6 & Suç ve Ceza (Dostoyevski) & 90 & 10,7 \\
\hline $\begin{array}{l}\text { Çalıkuşu (Reşat } \\
\text { Güntekin) }\end{array}$ & Nuri & 79 & 9,4 & Sefiller (Victor Hugo) & 78 & 9,2 \\
\hline
\end{tabular}


Tablo 8'e göre eğitim fakültesi öğrencilerini en çok etkilendikleri yerli kitaplar, "Aşk, Piraye ve Çalıkuşu"dur. Öğrencilerin en çok etkilendikleri yabancı kitaplar, "Uçurtma Avcısı, Suç ve Ceza ve Sefiller"dir.

Tablo 9: Bölümlere Göre Eğitim Fakültesi Öğrencilerinin En Çok Okudukları ve Etkilendikleri Kitaplar

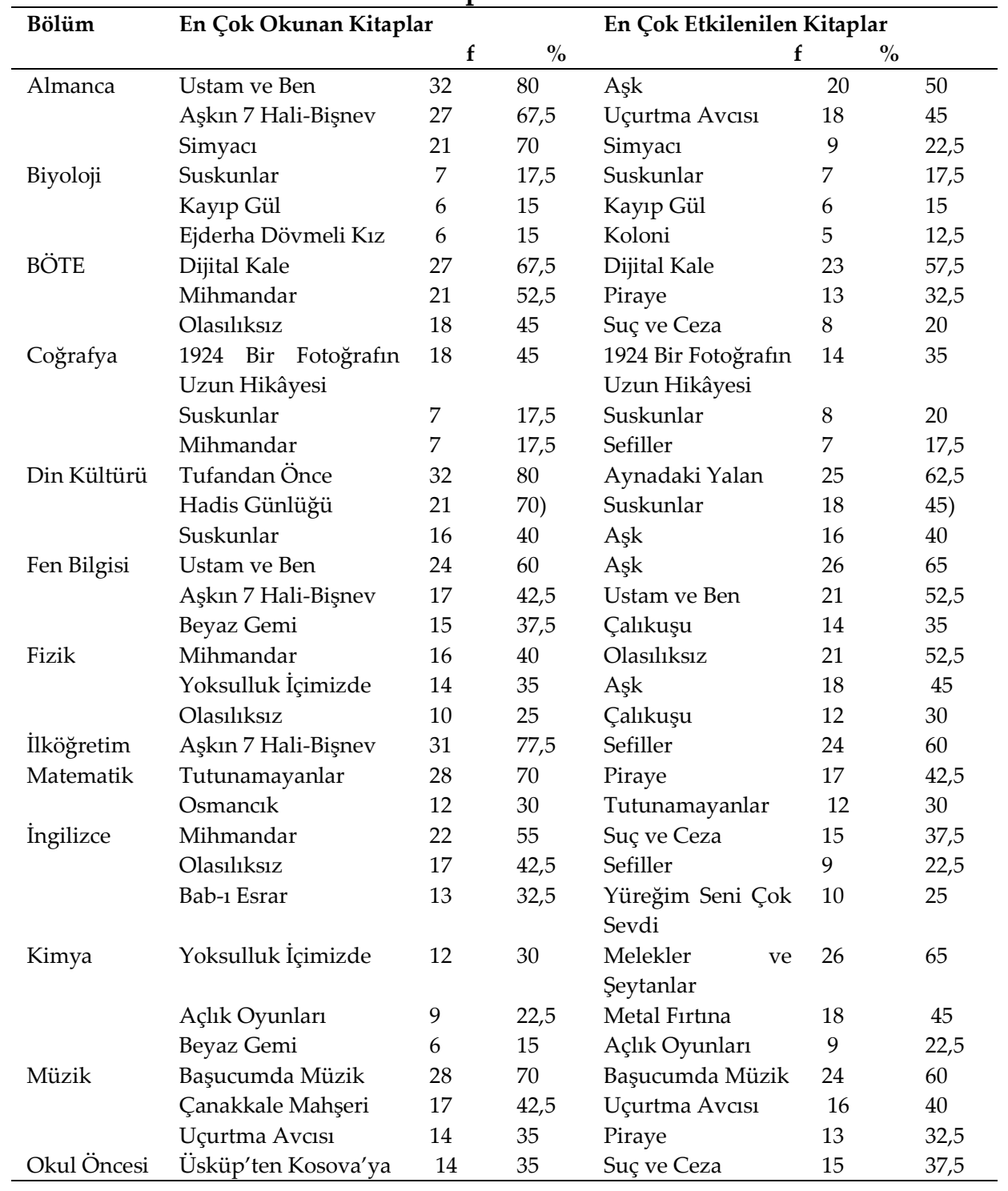




\begin{tabular}{|c|c|c|c|c|c|c|}
\hline & Fatih Harbiye & 10 & 25 & $\begin{array}{l}\text { Yüreğim Seni Çok } \\
\text { Sevdi }\end{array}$ & 12 & 30 \\
\hline & İz & 8 & 20 & Katre-i Matem & 9 & 22,5 \\
\hline Orta & Ustam ve Ben & 21 & 60 & Ustam ve Ben & 21 & 52,5 \\
\hline Öğretim & Tutunamayanlar & 17 & 42,5 & Tutunamayanlar & 14 & 35 \\
\hline Matematik & Mihmandar & 15 & 37,5 & Uçurtma Avcısı & 8 & 20 \\
\hline \multirow[t]{3}{*}{ PDR } & Uçurtma Avcisı & 19 & 47,5 & Uçurtma Avcisı & 23 & 57,5 \\
\hline & Olasılıksız & 15 & 37,5 & Olasılıksız & 15 & 30 \\
\hline & Ustam ve Ben & 12 & 30 & Aşk & 11 & 27,5 \\
\hline \multirow[t]{3}{*}{ Resim } & Ustam ve Ben & 28 & 70 & Piraye & 29 & 72,5 \\
\hline & Mihmandar & 23 & 57,5 & Çalıkuşu & 17 & 42,5 \\
\hline & Aşkın 7 Hali-Bişnev & 18 & 45 & Sefiller & 15 & 37,5 \\
\hline \multirow[t]{3}{*}{ Sinif } & Ustam ve Ben & 19 & 47,5 & Çalıkuşu & 9 & 22,5 \\
\hline & Dünden Bugüne & 17 & 42,5 & Suç ve Ceza & 7 & 17,5 \\
\hline & Uçurtma Avcısı & 6 & 15 & Uçurtma Avcısı & 5 & 12,5 \\
\hline Sosyal & Ustam ve Ben & 29 & 72,5 & Aşk & 26 & 65 \\
\hline \multirow[t]{2}{*}{ Bilgiler } & Aşkın 7 Hali-Bişnev & 25 & 62 & Suç ve Ceza & 23 & 57,5 \\
\hline & Katre-i Matem & 18 & 45 & $\begin{array}{l}\text { Gün Olur Asra } \\
\text { Bedel }\end{array}$ & 17 & 42,5 \\
\hline \multirow[t]{3}{*}{ Tarih } & Şu Çılgın Türkler & 19 & 47,5 & Şu Çılgın Türkler & 18 & 45 \\
\hline & Savaş ve Barış & 16 & 40 & Şah ve Sultan & 11 & 27,5 \\
\hline & Ermeni Tehciri & 14 & 35 & $\begin{array}{l}\text { Cengiz Han'a } \\
\text { Küsen Bulut }\end{array}$ & 9 & 22,5 \\
\hline Türk Dili ve & Beyaz Gemi & 22 & 55 & İki Şehrin Hikâyesi & 25 & 62,5 \\
\hline \multirow[t]{2}{*}{ Edebiyatı } & Derviş ve Ölüm & 18 & 45 & Uçurtma Avcisı & 21 & 52,5 \\
\hline & Yeni Turan & 13 & 32,5 & Derviş ve Ölüm & 18 & 45 \\
\hline \multirow[t]{3}{*}{ Türkçe } & Mihmandar & 15 & 37,5 & Suç ve Ceza & 9 & 22,5 \\
\hline & $\begin{array}{l}\text { Babil'de Ölüm } \\
\text { İstanbul'da Aşk }\end{array}$ & 10 & 25 & Sefiller & f6 & 15 \\
\hline & Ustam ve Ben & 9 & 22,5 & Piraye & 6 & 15 \\
\hline \multirow{3}{*}{$\begin{array}{l}\text { Zihin } \\
\text { Engelliler }\end{array}$} & Aşkın 7 Hali-Bişnev & 26 & 65 & Piraye & 18 & 45 \\
\hline & Ustam ve Ben & 21 & 52,5 & Çalıkuşu & 16 & 40 \\
\hline & Uçurtma Avcisı & 18 & 45 & $\begin{array}{l}\text { Aşkın } \quad 7 \quad \text { Hali- } \\
\text { Bişnev }\end{array}$ & 9 & 22,5 \\
\hline
\end{tabular}

Tablo 9'a göre en çok okunan yazarların İskender Pala, Elif Şafak, Sinan Yağmur ve Canan Tan olduğu görülmektedir. Popüler yabancı kitapların Fizik, Kimya, Biyoloji, PDR, İngilizce, Müzik ve Bilgisayar Öğretmenliğinde okunduğu görülmüştür. Çalıkuşu; Sınıf Fizik, Resim, Fen Bilgisi, Zihin Engelliler Öğretmenliğinde en çok etkilenilendir. Sadece Din Kültüründe okunan ve etkilenilen bütün kitaplar Türk yazarlarındır. Dünya 
edebiyatlarından en fazla okunan kitaplar "Sefiller" (Türkçe, İngilizce, İlköğretim Matematik, Coğrafya, Resim Öğretmenliğinde), "Suç ve Ceza" (Türkçe, Sınıf, Bilgisayar, Okul Öncesi, Sosyal Bilgiler Öğretmenliğinde)'dır. Dünya edebiyatlarından en fazla Rus Edebiyatı okunmaktadır. Popüler kitaplardan "Uçurtma Avcısı"; Sınıf, PDR, Edebiyat, Almanca, Müzik, Ortaöğretim Matematik, Zihinsel Engelliler Öğretmenliğinde; "Olasılıksız" ise en fazla Bilgisayar, PDR, Fizik ve İngilizce Öğretmenliğinde okunmaktadir.

\section{Tartışma, Sonuç ve Öneriler}

Toplam yirmi bir bölümde öğrenim gören öğretmen adaylarının okuma alışkanlıklarının belirlenmesi amacıyla yapılan bu araştırmanın verilerine göre; eğitim fakültesi öğrencilerinin çoğunlukla bir-beş kitap okudukları ve dolayısıyla az okur oldukları tespit edilmiştir. Türkiye Okuma Kültürü Haritasına (2013) göre; yılda ortalama 7,2 kitap okunmaktadır. Kuş ve Türkyılmaz 'ın (2010) araştırmalarında da Türkçe ve Sosyal Bilgiler Öğretmenliği öğrencilerinin büyük bir kısmının, yılda on kitaptan daha az kitap okuduğu belirlenmiştir. Ancak Yalman, Özkan ve Kuluca'nın (2013) çalışmasında öğretmen adaylarının genelinin haftada en az bir veya birden fazla kitap okuduğu; Geçgel ve Burgul (2009)'un çalışmasında 1. ve 4. sınıf öğretmen adaylarının çoğunluğunun ayda bir kitap; Aslantürk ve Saracoğlu (2010) araştırmasında da Sınıf Öğretmenliği 4. sınıf öğrencilerinin yılda en az on iki kitap okuduklarını tespit edilmiştir. Bu farklılıkların nedeninin, bazı eğitim fakültelerinde ortaöğretim ya da güzel sanatlar eğitiminin olmaması ve araştırmaların belirli sınıf düzeylerinde yapılmasının olduğu söylenebilir. On beş kitaptan daha fazla okuyan öğrencilerin en çok olduğu yani okuma alışkanlığı genel olarak iyi olan bölümler Tarih, Türk Dili ve Edebiyatı ve Din Kültürü'dür. Bu bölümlerin sözel içerikli olmalarının da kitap okumalarında etkili olduğu söylenebilir. Öğretmen adaylarının meslekî yaşamları boyunca iyi düzeyde okuma alışkanlığına sahip olmalarının önemi göz önüne alındığında mevcut okuma alışkanlıklarının istenen düzeyde olmamasının sorun teşkil ettiği görülmektedir.

Öğrencilerin okumalarına engel olan unsurlar arasında sırasıyla "Okuma alışkanlığının olmaması"; "Arkadaşlarla vakit geçirmek”; "Derslerin yoğunluğu"; "Bilgisayar ve internet kullanmak, TV izlemek" yer almıştır. Alanyazında yapılan araştırmalarda da okuma alışkanlığına engel olan unsurlar derslerin yoğunluğu (Aslantürk ve Saracoğlu 2010; Geçgel ve Burgul, 2009; Kolaç, 2007; Kuş ve Türkyılmaz, 2010; Yalman, Özkan ve Kuluca, 2013), okuma alışkanlığının olmaması (Geçgel ve Burgul, 2009; 
Odabaş vd, 2008; Yılmaz, 2006) internet ve TV izlemek (Aslantürk ve Saracoğlu 2010; Kuş ve Türkyılmaz, 2010; Lehr, 2005; Odabaş vd, 2008; Sağlam vd. 2008; Yalman, Özkan ve Kuluca, 2013) arkadaşlarla vakit geçirmek (Aslantürk ve Saracoğlu 2010) ve KPSS (Geçgel ve Burgul, 2009; Kolaç, 2007; Kuş ve Türkyılmaz, 2010) olarak sıralanmıştır. Öğretmen adaylarının okuma alışkanlığına sahip olmadıklarını belirtmeleri, bu alışkanlığın yükseköğretimden önce kazanılmasına daha fazla önem verilmesi gereğine dikkat çekmektedir.

Araştırmada öğretmen adaylarının okuma alışkanlıklarının sınıf düzeyine belirgin biçimde farklılaşmadığı tespit edilmiştir. Alanyazında yapılan çalışmalarda da (Özbay vd., 2008; Sağlam vd., 2008; Saracaloğlu vd., 2003; Yılmaz ve Benli, 2010) öğretmen adaylarının okuma alışkanlıklarının sınıf düzeyine göre büyük oranda farklılaşmadığı belirlenmiştir.

Bölümlere göre öğrencilerin okumalarında etkili olan unsurlarda ilk sırada "arkadaş tavsiyesi" yer almaktadır. Okuma alışkanlığının diğer bölümlere kıyasla daha iyi olduğu bölümlerde ilk sırada "hocaların tavsiyesi" yer almaktadır. Türkiye Okuma Kültürü Haritasına (2013) göre de katılımcıların çoğunluğu okuma tercihlerini tavsiye edilen kitaplardan yana kullanmaktadır. Sağlam, Suna ve Çengelci'nin (2008) araştırmasında öğretim elemanlarının öğrencileri okumaya yönlendirmelerinin öğretmen adaylarının okuma alışkanlıklarını olumlu yönde etkilediği ve okuma alışkanlığıyla arkadaş ilişkilerinin çift yönlü olumlu olarak etkilendiği tespit edilmiştir. Okumada etkili olan diğer unsurlar "Kişisel tercihler-konuya ilgi duyma", "Yazar" ve Kütüphane" dir. Ayyıldız, Bozkurt ve Canlı'nın (2006) çalışmasında da öğrencilerin kitap tercihinde konunun ilgi çekiciliği; Geçgel ve Burgul'un (2009) araştırmasında ise öğretmen adaylarının kitap seçimini etkileyen faktörlerde "konu" ve "yazar" ilk sıralardadır. Mostert ve Wikan'in (2008) araştırmasında kişisel tercihlere bağlı olarak okumanın, okuma alışkanlığını arttırdığı sonucuna ulaşılmıştır. Bu noktada öğretmen adaylarının okuyacakları materyalleri kendi ilgilerine göre seçmelerinin okuma alışkanlıklarına olumlu katkılarının olacağı ifade edilebilir. Nathanson, Pruslow ve Levitt'in (2008) araştırmasında da öğretmen adaylarının okumanın meslekî gelişimlerine katkısının farkında oldukları ancak kişisel ilgiye dayalı okumalarının istenen orta düzeyde olduğu belirlenmiştir.

Bölümlere göre öğrencilerin en çok tercih ettikleri türler arasında yirmi bölümde ilk sırada roman ve hikâye yer almaktadır. Alan yazındaki çalışmalarda da öğretmen adaylarının en çok tercih ettikleri tür romandır (Ayyıldız, Bozkurt, Canlı, 2006; Geçgel ve Burgul, 2009; Kuş ve Türkyılmaz, 
2010; Yılmaz, 2009). 10 bölümde en çok tercih edilen ikinci kitap türü kişisel gelişim, 7 bölümde dinî kitaplar, 5 bölümde ise tarih-felsefe kitaplarıdır. Şiir türünün az sayıda öğrenci tarafından okunduğu görülmüştür. Benzer şekilde Kuş ve Türkyılmaz'ın (2010) araştırmalarında Türkçe ve Sosyal Bilgiler Bölümlerindeki öğretmen adaylarının, şiiri az okudukları tespit edilmiştir. Ancak Geçgel ve Burgul'un (2009) araştırmasında öğretmen adaylarının okumayı tercih ettikleri edebî türler arasında "şiir" ikinci sıradadır. Alanlarıyla ilgili bilimsel kitap az sayıda öğrenci tarafından tercih edilmiştir. Roman-hikâye ve dinî kitaplar her bölümde en çok okunan türlerdir. Erişkon Cangi' inl (2008) araştırmasında da öğretmen adaylarının en çok edebî eserleri, ikinci sırada ise kişisel gelişim, bilim kurgu, tarih, felsefe alanında yazılmış kitapları okudukları tespit edilmiştir.

Araştırmada sayısal ve sanat ağırlıklı bölümlerin bir saatten az okudukları belirlenmiştir. Ancak bazı çalışmalarda (Gholipour, 2012; Sağlam, Suna ve Çengelci, 2007; Saracaloğlu vd., 2003; Temizkan ve Sallabaş, 2009) üniversite öğrencilerinin eğitim gördükleri bölümlerin alışkanlıkları üzerinde genelde belirgin biçimde etkisinin olmadığı belirlenmiştir. Ağırlıklı olarak bölümlerde okumanın, internetin ve TV'nin bir saatten az; arkadaşlarla vakit geçirmenin iki- üç saat olduğu görülmüştür. Karaman (2010), araştırmasında öğretmen adaylarının haftada ortalama bir-beş saati TV izleyerek ve internet kullanarak geçirdikleri ve bu yayın organlarını büyük oranda bilgiye erişim ve gündemden haberdar olmak için kullandıkları görülmektedir. RTÜK'ün (2013) TV izleme eğilimlerini ortaya koymak amacıyla yaptığı araştırmada katılımcların haftada ortalama iki-beş saat TV izlediği ortaya çıkmıştır. Alınyazında televizyon izlemeye ve internet kullanımına ayrılan zamanın kitap okumaya ayrılan zamanı olumsuz yönde etkilediği sonucuna ulaşılmıştır (Caplan 2005; Kuş ve Türkyılmaz, 2010; Mokhtari, Richard ve Gardner, 2009; Sağlam vd 2008; Yılmaz, 2006). Ancak alan yazındaki bazı araştırmalarda haftada 10-20 saat TV izleme ve internet kullanım süresinin medya okuryazarlığını arttırdığ (Karaman ve Karataş 2009) ve haftada on biryirmi saat bilgisayar kullanan öğretmen adaylarının; internetin öğretimde ve araştırmada kullanımı, öğretimde bilgi paylaşımında kullanımına yönelik tutumlarının yüksek olduğu (Yanık, 2010) belirlenmiştir. Bu bağlamda özellikle internet kullanımının okuma alışkanlığına olumlu katkılarının olduğu da söylenebilir.

Bütün bölümlerde en çok tercih edilen materyaller arasında ilk dörtte sosyal paylaşım sitelerindeki yazılar, edebî kitaplar, internet ortamındaki gazeteler ve dinî dergiler yer almıştır. Öğrencilerin ağırlıklı olarak edebî kitapları tercih ettikleri, alanlarındaki bilimsel kitapların bütün bölümlerde 
çok az öğrenci tarafından tercih edildiği görülmüştür. Yılmaz'ın (2009) araştırmasında da Türkçe Öğretmenliği öğrencilerinin genel olarak edebî kitapları tercih ettiği belirlenmiştir. Resim ve Tarih Öğretmenliği dışında büyük çoğunluğun alanıyla ilgili bilimsel bir dergi okumadığı belirlenmiştir. Aslantürk ve Saracoğlu (2010) ve Erişkon Cangil'in (2008) çalışmalarında da öğretmen adaylarının en az bilimsel kitapları okudukları belirlenmiştir. Kuş ve Türkyılmaz'ın (2010) çalışmalarında da öğretmen adaylarının akademik makaleleri neredeyse hiç okumadıklarını belirlemişlerdir. Bu durum, geleceğin öğretmenlerinin özellikle alanlarıyla ilgili bilimsel araştırmaları takip etmemeleri bakımından düşündürücüdür.

Gazetenin genellikle internet üzerinden okunduğu ve öğrencilerin güncel olayları takip ettikleri belirlenmiştir. Gazete dışında internette okunan yazılarda ise ilk sırada sosyal paylaşım sitelerindeki yazılar (özellikle Facebook ve Twitter) gelmektedir. Baran ve Ata (2013), üniversite öğrencilerinin internette en fazla derslerle ya da diğer eğitsel çalışmalarla ilgili bilgi ve paylaşımda bulunma" amacı olarak anında mesajlaşma servisleri ve sosyal paylaşım ağlarını kullandıklarını tespit etmiştir. Araştırmanın da bulgularını destekleyen bu durum, interneti sıklıkla eğitsel amaçla kullandıklarını göstermektedir. Bensoussan'ın (2009) İsrail'deki üniversite öğrencileri üzerinde yaptığı araştırmada da internet okumalarının ağırlıklı olarak öncelikle sosyal daha sonra akademik amaçla okunduğu tespit edilmiştir.

Sanatsal-kültürel dergileri en fazla Zihin Engelliler, Resim, İngilizce ve Müzik bölümündeki öğretmen adaylarının okudukları ancak bütün bölümlerde ağırlıklı olarak dinî dergilerin okunduğu tespit edilmiştir. Yılmaz'ın (2009) araştırmasında da öğretmen adaylarının yaklaşık üçte birinin hiç dergi okumadığı, dergi okuduğunu söyleyen öğrencilerin de büyük bir çoğunluğunun sanatsal-edebî dergilerle kültür dergileri okuduğu belirlenmiştir. Bu bağlamda öğretmen adayları en azından alanlarıyla ilgili dergileri okumaları yönünde de öğretim elemanları tarafından teşvik edilmelidir.

Öğretmen adaylarının en çok etkilendikleri yerli kitaplar ise "Aşk, Piraye ve Çalıkuşu"dur. Öğretmen adaylarının en çok etkilendikleri yabancı kitaplar, "Uçurtma Avcısı, Suç ve Ceza ve Sefiller"dir. En çok okunan Türk yazarların İskender Pala, Elif Şafak, Sinan Yağmur, Canan Tan ve Reşat Nuri Güntekin olduğu; en çok okunan yabancı yazarların ise Khaled Hosseini, Adam Fewer, Cengiz Aytmatov, Dostoyevski ve Victor Hugo olduğu tespit edilmiştir. Popüler yabancı kitapların en çok Fizik, Kimya, Biyoloji, PDR, İngilizce, Müzik ve Bilgisayar Öğretmenliğinde okunduğu görülmüştür. 
Popüler kitaplardan en fazla "Uçurtma Avcısı" ve "Olasılıksız" okunmaktadır. Türkiye Okuma Kültürü Haritasına (2011) göre de en çok okunan yazarlar arasında Elif Şafak, Canan Tan ve Dostoyevski yer almaktadır. Araştırmada dünya edebiyatlarından en fazla Rus edebiyatının okunduğu belirlenmiştir. Ayyıldız, Bozkurt ve Canlı (2006) da araştırmalarında öğretmen adaylarının klasik olarak kabul edilen eserlere değer verdiklerini tespit etmiştir.

Sonuç olarak okuma alışkanlığı ve kültürü, 21. yüzyılın ortaya çıkardığı profesyonel öğretmen anlayışının temsilcisi olacak öğretmen adaylarının sahip olması gereken vasıflardandır. Öğretmen adayları; yeterli düzeyde okuma alışkanlığı ve kültürü edinmek suretiyle öncelikli olarak alanlarıyla ilgili gelişme ve araştırmaları takip edip meslek hayatlarında kullanabilen, yetkin ve entelektüel bireyler haline gelecektir.

\section{Kaynakça}

AKYOL, H. (2005). Türkçe ilkokuma yazma öğretimi. 4. Baskı, Ankara: PegemA Yayıncilik.

ASLANTÜRK, E. \& SARACALOĞLU, A., S. (2010). Sınıf öğretmenlerinin ve sınıf öğretmeni adaylarının okuma ilgi ve alışkanlıklarının karşılaştırılması. Anadolu Üniversitesi Sosyal Bilimler Dergisi, 11 (1), 155-176.

AYYILDIZ M., Ü. BOZKURT \& S. CANLI (2006). Okuma Kültürü Üzerine Bir Araştırma. Millı̂ Eğitim (Edebiyat Eğitimi ve Öğretimi Özel Sayısı), Say1:169, s. 277-296.

BAMBERGER, R. (1990). Okuma alı̧̧kanlığını geliştirme. (Çev.: B.Çapar) Ankara: Kültür Bakanlığı.

BARAN B. \& ATA F. (2013). Üniversite öğrencilerinin web 2.0 teknolojileri kullanma durumları, beceri düzeyleri ve eğitsel olarak faydalanma durumları. Eğitim ve Bilim, 38(169), 192-208.

BENSOUSSAN, M. (2009): Reading preferences and expectations of multilingual Israeli university students, Journal of Multilingual and Multicultural Development, 30:6, 465-480.

BLAHA, B. A. \& BENNETT, J. M. (1993). Yeni okuma teknikleri. (D. Şahiner, Çev.). İstanbul: Rota Yayınları.

BÜYÜKÖZTÜRK, Ş. , ÇAKMAK, E. K. , AKGÜN, Ö. E. ,KARADENİZ Ş. ve DEMIREL, F. (2008). Bilimsel araştırma yöntemleri. Ankara: Pegem Akademi. 
CEKİNHAD. (2000, Şubat 17) 1998 Ceza hukuku, kriminoloji ve insan hakları derneği kamuoyu araştırmaları dokuz numaralı kamuoyu araştırması, www.po.metu.edu.tr/bh505.html-52k. (2000, Kasım 28).

CAPLAN, S.E. 2005. A social skill account of problematic internet use. Journal of Communication, 55(4). 721-736.

ÇOCUK VAKFI. (2006). Türkiye'nin Okuma Alışkanlığı Karnesi. İstanbul: Çocuk Vakfı Yayınları.

DEMİREL, Ö. (1999). İlköğretim okullarında Türkçe öğretimi. İstanbul: MEB Yayınları.

EC. (2006). Quality assurance in teacher education in Europe. Brussel. Belgium. bookshop.europa.eu/.../quality-assurance-in-te. Erişim tarihi: 30.10.2014.

ERIŞKON CANGILL, B. (2008). Okumayı Öğretmek - Almanca Öğretmen Adayı Gençlerin Okuma ve Kütüphane Kullanma Alışkanlıkları. Gençlĭgin İzdüşümü, Nilüfer Tapan Armağan Kitabı, Yay. Haz. Nilüfer Kuruyazıcı. İstanbul: Multilingual, 293-313.

GEÇGEL, H. \& BURGUL, F. (2009). Eğitim Fakültesi öğrencilerinin okuma ilgi alanları (Çanakkale örneği). TÜBAV Bilim Dergisi, 2(3): 341-353.

GHOLIPOUR J. (2012). Tebriz (İran) Üniversitesi Fars Dili ve Edebiyatı Bölümü Öğrencilerinin Okuma Alışkanlıkları Üzerine Bir Çalışma, Türk Kütüphaneciliği 26, 4 769-779.

GÖMLEKSIZZ, M.N. (2004). Kitap okuma alışkanlığına ilişkin bir tutum ölçeğinin geçerlik ve güvenirliği. Fırat Üniversitesi Sosyal Bilimler Dergisi, 14, 185- 195.

GÖNEN, M. (2007). Öğretim boyunca okuma alışkanlığı, okuma kültürü ve okullarda uygulama sorunları toplantısı. Ankara: MEB Yayınları.

KARAMAN, M. K. \& KARATAŞ, A. (2009). Media Literacy Levels of the Candidate Teachers, Elementary Education Online, 8(3), 798-808.

KARAMAN, M. K. (2010). Öğretmen Adaylarının TV ve İnternet Teknolojilerini Kullanma Amaç ve Beklentilerinin Medya Okuryazarlığı Bağlamında Değerlendirilmesi. Uşak Üniversitesi Sosyal Bilimler Dergisi, 3(2), 51-62.

KARASAR, N. (2008). Bilimsel araştırma yöntemi. Ankara: Nobel Yayınları.

KAYALAN, M. (2000). Etkili ve hızlı okuma sanatı. İstanbul: Alfa Basım.

KOLAÇ, E. (2007). Sınıf öğretmeni adaylarının okuyucu profilleri. Anadolu Üniversitesi VI. Ulusal Sınıf Ö̆̆retmenliği Ĕ̆itimi Sempozyumu, 27-29 Nisan, 209-214. 
KUŞ, Z. \& TÜRKYILMAZ, M. (2010) Sosyal Bilgiler ve Türkçe Öğretmeni adaylarının okuma durumları: (ilgi, alışkanlık ve okuma stratejilerini kullanım düzeyleri). Türk Kütüphaneciliği Dergisi, 24(1): 11-32.

KÜTÜPHANELER VE YAYIMLAR GENEL MÜDÜRLÜĞÜ (2011). Türkiye Okuma Kültürü Haritası. http://www.kygm.gov.tr/Eklenti/55,yonetici-ozetipdf.pdf?0. Erişim tarihi: 30.10.2014.

LEHR, F. (2005). Television wieving and writing. Http://ericir.syr.edu/plweb_cgi/fastweb?searchform+ericdb.

MEB (2006). Türkçe dersi öğretim programı ve kılavuzu. Ankara: MEB Yayınları.

MOKHTARI, K., REICHARD, C.A. \& GARDNER, A. (2009). The Impact of Internet and Television Use on the Reading Habits and Practices of College Students. Journal of Adolescent \& Adult Literacy, 52(7), 609-619.

MOSTERT L. \& WIKAN G. (2008): Reading habits and attitudes of primary school pupils in Namibia and Norway, Education as Change, 12(1), 95107

NATHANSON S., PRUSLOW J. \& LEVITT R. (2008.) The reading habits and literacy attitudes of inservice and prospective teachers results of a questionnaire survey, Journal of Teacher Education, 59(4), 313-321.

ODABAŞ, H., ODABAŞ, Z.Y. \& POLAT, C. (2008). Üniversite Öğrencilerinin Okuma Alışkanlığı: Ankara Üniversitesi Örneği. Bilgi Dünyası. 9 (2). 431-465.

ÖZBAY, M. (2007). Türkçe Özel Öğretim Yöntemleri II, Ankara: Öncü Kitap.

ÖZBAY, M., BAĞCI, H. \& UYAR, Y. (2008). Türkçe öğretmeni adaylarının okuma alışkanlığına yönelik tutumlarının çeşitli değişkenlere göre değerlendirilmesi. İnönü Üniversitesi Ĕ̆itim Fakültesi Dergisi, 9(15), 117- 136.

ÖZÇELEBİ, O. S. \& CEBECIOĞLU, N. S. (1990). Okuma alışkanlığı ve Türkiye. İstanbul: Milliyet.

ÖZDEMİR, E. (1967). İlkokul Öğretmenleri İçin Türkçe Öğretimi Kılavuzu. Ankara: Ansiklopedi Yayınları.

RTÜK, (2013). Televizyon İzleme Eğilimleri Araştırması 2012 Mart Kamuoyu, Yayın Araştırmaları Ve Ölçme Dairesi Başkanlığı.

SAĞLAM, M., SUNA, Ç. \& ÇENGELCİ, T. (2008). Öğretmen adaylarının okuma alışkanlığını etkileyen görüş ve önerileri. Milli Ĕ̆itim. 178, 823.

SARACALOĞLU, A.S., BOZKURT, N. \& SERIN, O. (2003). Üniversite öğrencilerinin okuma ilgileri ve okuma alışkanlıklarını etkileyen faktörler. Ĕ̆itim Araştırmaları, 4, 149-157. 
SEVER, S. (2011), Türkçe öğretimi ve tam öğrenme. Ankara. Anı Yayıncılık. TDK (1998). Türkçe Sözlük. Ankara: Türk Dil Kurumu Yayınları.

TEMIZKAN M. \& SALLABAŞ M. E. (2009). Öğretmen Adaylarının Okuma ve Yazmaya Yönelik Tutumlarının Karşılaştırılması. Elektronik Sosyal Bilimler Dergisi, C.8 S.27 (155-176) ISSN:1304-0278.

TÜRKIYE OKUMA KÜLTÜRÜ HARITASI (2011). T.C. Kültür Bakanlığı Yayınları, $\quad$ http://basin.kulturturizm.gov.tr/TR,7074/turkiyeokumakulturu- haritasi-arastirmasi-sonuclari-ac-.html.

YALMAN, M., ÖZKAN, E. \& KUTLUCA, T. (2013). Eğitim fakültesi öğrencilerinin kitap okuma alışkanlıkları üzerine betimsel bir araştırma: Dicle Üniversitesi örneği. Bilgi Dünyası, 14 (2) 291-305.

YANIK C. (2010). Öğretmen adaylarının bilgisayar okuryazarlık algıları ile internet kullanımına yönelik tutumları arasındaki ilişki. Hacettepe Üniversitesi Eğitim Fakültesi Dergisi (H. U. Journal Of Education) 39: 371-382 [2010]

YAZICI, E. (2003). Türk üniversite gençliği araştırması: Üniversite gençliğinin sosyo-kültürel profili. Ankara: Gazi Üniversitesi.

YILMAZ, B. (1993). Okuma Alışkanlığı ve Halk Kütüphanelerinin Rolü. Ankara: Kültür Bakanlığı, Kütüphaneler Genel Müdürlüğü Yayınları.

YILMAZ, B. (2004). Okuma alışkanlığı ve öğretmen. Okuma Kültürü ve Okullarda Uygulama Sorunları Toplantısı. Ankara: Milli Eğitim Bakanlığı Yayını, 2007, 133-142.

YILMAZ, M. (2009). Üniversite Öğrencilerinin Okuma Alışkanlığ İnceleme (Cumhuriyet Üniversitesi Eğitim Fakültesi Türkçe Eğitimi Bölümü Örneği). Çukurova Üniversitesi Eğitim Fakültesi Dergisi. 3(37), 144-167.

YILMAZ, M. \& BENLİ, N. (2010). Sınıf Öğretmeni Adaylarının Okuma Alışkanlığına Yönelik Tutumlarının Bazı Değişkenlere Göre İncelenmesi. Erzincan Eğitim Fakültesi Dergisi, 12(1): 281-291.

YILMAZ, Z. A. (2006). Sınıf Öğretmeni Adaylarının Okuma Alışkanlığı. Illköğretim Online, 5(1): 1-6. 